\title{
THE BARCLAY RECORD BOOK AND ITS EAST JERSEY MINUTES: AN EARLY LOOK AT CONTEXT AND CONTENT ${ }^{1}$
}

\author{
BY MAXINE N. LURIE
}

Prof. Maxine Lurie is a history professor at Seton Hall University

An effort to place in context the Minutes of the East Jersey Proprietors in London (1682-1684), transcribed from the Record Book of Robert Barclay and printed in this issue of the Journal of Rutgers University Libraries, must begin with the origins of New Jersey itself.

This state resulted from seventeenth-century European efforts to colonize the Americas. It began first as a Dutch settlement (1624-1664), into which for a short time (1638$1655)$ the Swedes intruded. In 1664 England took over and for a very brief time what became New Jersey was part of New York. The Duke of York, however, quickly granted the land between the Hudson and Delaware rivers to two loyal friends, John, Lord Berkeley and Sir George Carteret. Thus, New Jersey became one of several proprietary colonies created during the Restoration period to reward supporters of the monarchy. ${ }^{2}$

In 1674 Berkeley deeded his half of the province to a group of Quakers led by Edward Billing and John Fenwick (West Jersey). After Carteret's death in 1680, his heirs sold their share (East Jersey) at auction to a group of twelve investors, most of them Quakers, each of whom quickly took in a partner. It is at this point that the minutes begin to record the meetings of the East Jersey proprietors in London, and the reader can observe the new investors coming into the group. Their number increased as the twenty-four shares of East Jersey (the total number remained the same) were sold off in fractions.

The proprietors quickly set out to collect information about their colony, as well as documents from the previous proprietors 
that might be of use in tracing their title and proving their claims. They worked to organize a government for the province, wrote a constitution ("The Fundamental Constitution of East Jersey") under which they assumed it would operate, and appointed Robert Barclay (1648-1690) as governor. ${ }^{3}$ Barclay remained in Scotland, but he selected deputies who went to the colony. The proprietors clearly assumed they had purchased the right to run the government as well as own the land of East Jersey. Whether they did possess such a right was disputed both by the governors of colonial New York, and, at times, by the British government. A legal opinion handed down in England maintaining they were entitled to rule failed to resolve the issue; in fact a resolution only occurred when both the East Jersey and West Jersey proprietors officially surrendered their political rights in 1702. At that point New Jersey became a royal colony.

The new owners of East Jersey valued their province for its lands. Each proprietor expected to receive dividends on his investment in the form of land in the colony that could be rented and/or sold to settlers. In an effort to ensure that their lands would be taken up they encouraged residents in England, Ireland, and Scotland and elsewhere to move to New Jersey. Robert Barclay was particularly active in working to gather immigrants in Scotland to make the voyage. For a few years in the 1680s he was successful, but well before his death in 1690 the number of immigrants from Scotland declined. Still, the Scottish involvement in East Jersey impacted the religious and ethnic composition of the colony through the eighteenth century particularly as some became prominent and politically powerful. More often Presbyterian than Quaker, they were also inclined to side with the patriots in the American Revolution.

In the 1680s, while Robert Barclay and most of the other East Jersey proprietors remained in England and Scotland, a small group did migrate to the colony. In 1685, to facilitate the governance of the colony and to better handle the distribution of lands, the proprietors authorized the creation of a Board of Proprietors in the colony. The East Jersey Board of Proprietors 
first met on April 9, 1685. They remained an important force in the colony even after the surrender of 1702 because in New Jersey, both East and West, the proprietors retained title to their lands even after the Crown took over the government. In fact they would keep that title in the case of East Jersey until 1998 and in West Jersey down to the present. ${ }^{4}$

The book of records that the state purchased in June 2005 consists of materials assembled by the London proprietors and then copied so that they could be sent to Scotland for use by Robert Barclay in his capacity as governor of East Jersey. Robert Barclay, Laird of Ury, was an early Quaker leader and theologian from a prominent Scottish family. ${ }^{5}$ He was related to several important Scottish nobles, and was actively involved in Quaker affairs. His political, economic, and religious connections were important reasons why the other proprietors wanted to pull him into the East Jersey project, and they also contributed to his ability to gather support for the enterprise. At the same time he was interested in colonization and had previously asked William Penn about Scottish participation in Pennsylvania. ${ }^{6}$ Barclay was given a $1 / 24$ share of New Jersey, and the governorship, even as he used his influence to bring a large number of Scots along-until some forty-five (of at one point eighty-five proprietors) were involved.

There are fifty-six "folios," as well as five maps purchased at the same time that had been bound in the record book. ${ }^{7}$ The Minutes of the London Proprietors comprise the last set of documents in the collection. These records were in the hands of the Barclay family for centuries, deposited for a time in the Friends Library in London, and then sold to a private collector. ${ }^{8}$ He later put them up for auction, the point at which the state of New Jersey obtained them.

The materials assembled for Barclay were clearly intended to help him defend the proprietors' title and territorial claims (including Staten Island)-thus there are copies of earlier charters and deeds, maps of New Jersey and New York harbor. For him to understand the history of the colony, those who were already there, and preexisting disruptive disputes with 


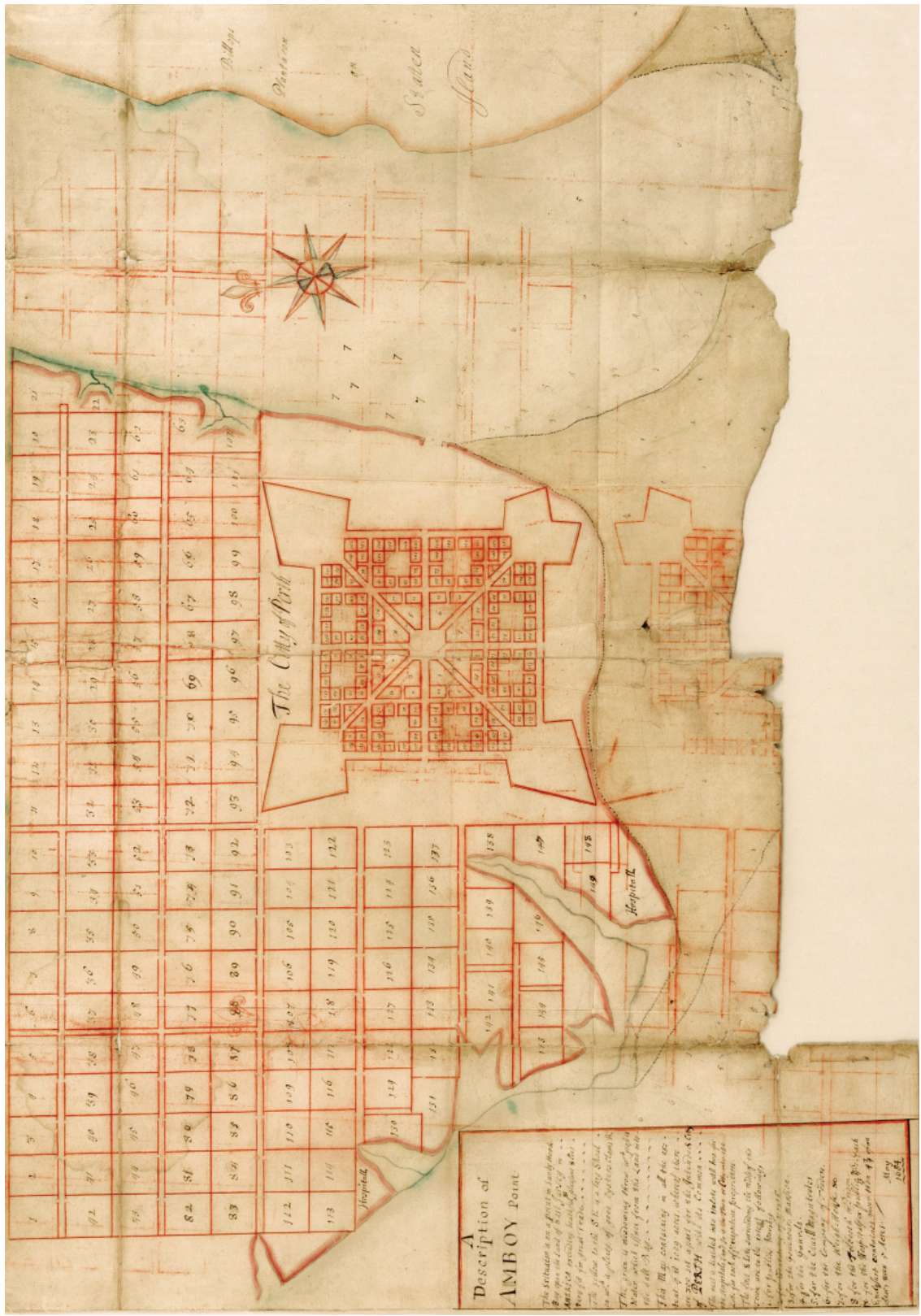

Figure 2.1 Map of "The Citty of Perth," 1684 from the 2005 purchase (New Jersey State Archives). In this colored planning map, there is bleeding from folding of the map in the canal between East Jersey and Staten Island and south of the planned city. 


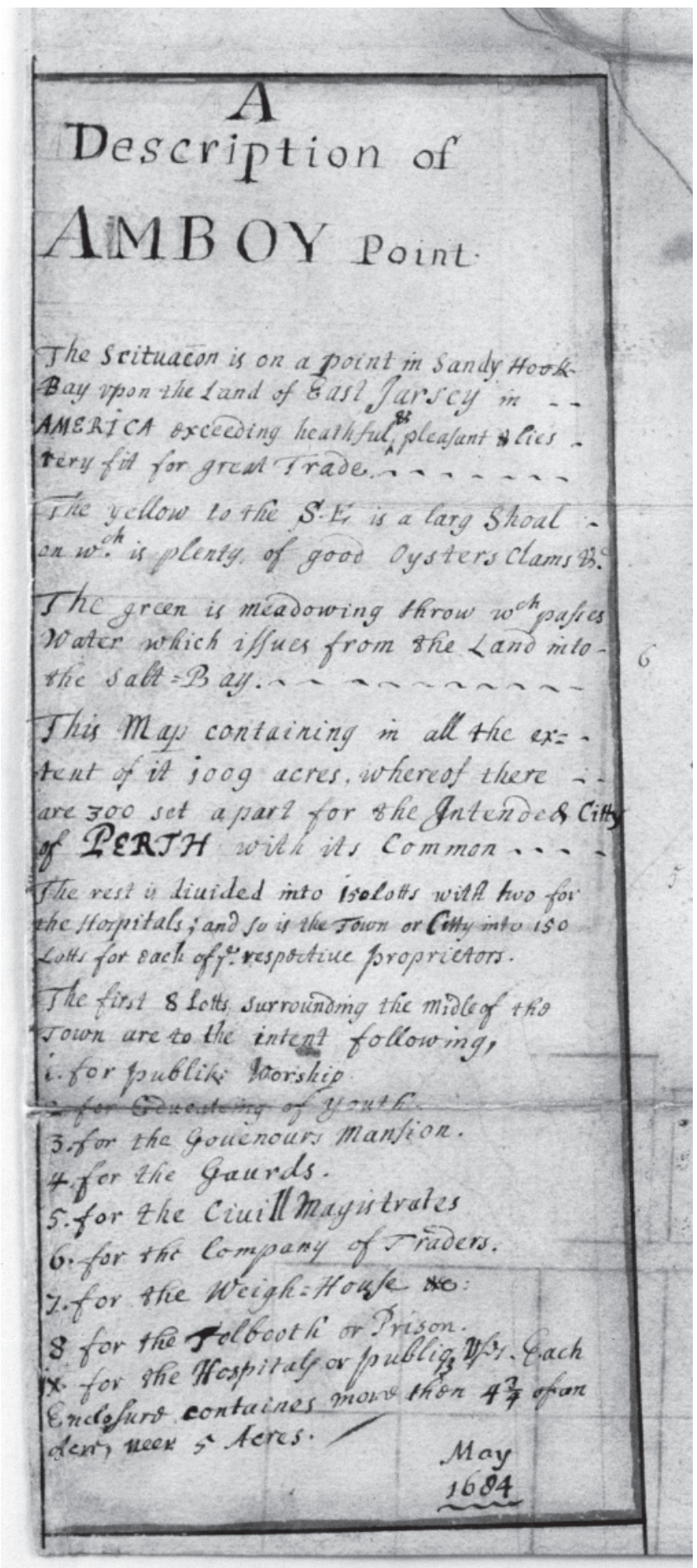

है 
settlers, the collection had copies of letters and instructions to earlier governors and surveyors, and even a description of the seven settled towns. ${ }^{9}$ There are instructions for laying out Perth Amboy, intended as the capital and chief port of the colony, as well as a map of what the London planners apparently thought it ought to look like. Designed to fit the landscape of what was first called Amboy point, this included a very prominent fort. The last document included was the minutes of proprietary meetings through March 4, 1684.

Assessing exactly what in this larger collection is new will take considerable time and patience, and in same cases a word-byword comparison. At some point copies of some of this material, possibly two-thirds, more or less, were sent to the colony as well as to Barclay. ${ }^{10}$ They survived and became part of the records of the colony and then the state. Early New Jersey records were first published by Aaron Leaming and Jacob Spicer in 1758; some of the materials, including in particular early letters, were then printed verbatim in Samuel Smith's History of the Colony of Nova-Caesaria or New-Jersey in 1765. In the nineteenth century William A. Whitehead collected early New Jersey records and then compiled them, along with text from Leaming and Spicer, Smith, and other sources, into a series published by the New Jersey Historical Society in the first volumes of the New Jersey Archives (1880), as well as in his rambling East Jersey under the Proprietary Governments (1875). In the early 1960s Julian Boyd published New Jersey's "Concessions," and constitutions in a "modern scholarly edition." ${ }^{12}$ The more recent edition of The Papers of William Penn, while not repeating the same material, adds a number of letters between Penn and Barclay about the settlement of both Pennsylvania and New Jersey that throw additional light on Barclay and his efforts to woo Scottish colonists to the Americas. ${ }^{13}$

Leaming and Spicer's eighteenth-century collection includes a very interesting observation. Immediately after the East Jersey Fundamental Constitutions; they note

It appears on Reading the foregoing Instrument that 
in sundry Places the Sense is not compleat, but it is likely to be occasioned by Omissions and neglects in Recording, and therefore if the Original can be come at, it will be proper to re-examine the foregoing copy therewith. ${ }^{14}$

It will take close analysis to determine differences between the version printed nearly 250 years ago and "The 24 Fundamentall Constitutions" in the Barclay manuscript. ${ }^{15}$ Leaming and Spicer also noted that they could not find Robert Barclay's commission as governor, only the text of it quoted in the commissions of his deputies (which they used). ${ }^{16}$ There is a copy of the Barclay commission in the manuscript.

The minutes of the East Jersey Board of Proprietors meeting in East Jersey (then New Jersey), have been published in four volumes that cover the period from 1685 to $1794 .{ }^{17}$ Missing in the volumes are the records from 1705 to 1724 . It is not clear whether these ever existed. It is possible that the board either did not meet during that time, or met and did not keep records, or that they have been long lost. ${ }^{18}$ Records of the Board from 1794 to 1998 exist in manuscript form and were obtained by the New Jersey State Archives when the proprietors disbanded. The West Jersey proprietors' records have not been printed, but recently they were deposited at the State Archives. These are all, published or not, records of meetings held on this side of the Atlantic. They do not include minutes of the meetings held in London.

Thus the fifty-sixth document in the Barclaybook, the London Minutes printed here, has not been previously published. In fact, it appears to have been rarely seen by scholars. Only two citations have been found specifically to the London Minutes in the Barclay papers, and both while they were at the Friends Library. ${ }^{19}$ There appear to be no references to them in the major sources on colonial New Jersey; nor are there any in works written about the East Jersey proprietors. While McCormick worked on colonial New Jersey, and published From Colony to State, 1609-1789 in 1964, and Wesley Frank Craven wrote 
New Jersey and the English Colonization of North America (1964), the most extensive work done on the New Jersey proprietors was by Princeton historian John Pomfret, who wrote several articles tracing the early purchasers of East Jersey proprietary shares (as well as of West Jersey shares), and then described the early history of both colonies in great detail in two books, one on East the other West Jersey. He also wrote a shorter book, The New Jersey Proprietors and Their Lands. ${ }^{20}$ He was unaware of the London Minutes. John T. Cunningham, who in The East of Jersey wrote an overview of the proprietors through several centuries, also was unaware of these records. ${ }^{21}$ Several scholars have written about the Scottish colonization plans, most recently Ned C. Landsman in Scotland and Its First American Colony, 1683-1765. He did look at the minutes and briefly cites them, but his emphasis was on East Jersey as a Scottish colony, and on events that primarily took place before or after the minutes were sent to Barclay. ${ }^{22}$

It is no wonder that McCormick, who besides being a prominent New Jersey history scholar was a member of both the East and West Jersey proprietary boards and hence quite interested in their history, became excited when he looked at the Barclay materials in the State Archives just a few months before he died.

What can we glean from these records that we do not already know? For some of the documents, in particular those printed over the years, a greater confidence on their accuracy than Leaming and Spicer could have had. From the map of Perth Amboy, which does appear to be something new, we gain information about plans for a capital well worth pondering. The surprising suggestion of a fort makes sense in an area that had changed hands between the Dutch and English four times between 1663 and 1674. Jamestown started as a fort, and nearby Manhattan Island had a fort at its tip. ${ }^{23}$ In East Jersey the planned fort was never built.

The London Minutes, recording the forty-one meetings held from June 6, 1682 to March 4, 1684, give us a better sense of who took the initiative for the proprietorship, and possibly 
more insight into the reasons why. ${ }^{24}$ William Penn was present at early meetings, but disappeared from the attendance list once he left for Pennsylvania. He visited East Jersey several times between 1682 and 1684, working to calm the waters between early settlers and newly arriving proprietary officials, and reporting to Barclay, who was in Scotland, and others. Records went back and forth for consultation and signatures. The impression the minutes leave is that a surprising amount of the early direction for the colony came from London merchants, rather than from Penn or Barclay. East Jersey does, briefly, become a Scottish project, but more control appears centered in London than Pomfret thought, at least until after the Barclay records were sent to Scotland..$^{25}$

Also surprising, perhaps, although discussed by Pomfret, is the degree to which this was a business rather than religious venture from the start. The minutes show businessmen working on land distribution, sending a ship with "cargo" to diversify sources of income and increase their profits while collecting funds from the investors to cover their expenses. Not much is said about protecting Quakers. Of course the additional investors brought in, particularly by Barclay, were not all Quakers. As noted above, a fair number were Scotch Presbyterians, some of whom then settled in the colony and made a difference in its composition as well. ${ }^{26}$

Finally the minutes show that the London proprietors operated theirventure much like the proprietors of Carolina, also a proprietorship in which there were multiple holders (though unlike New Jersey, there were never fractional holders) ${ }^{27}$ They also collected money from each other to cover expenses, and sent goods for trade to make a profit. Penn collected money from the First Purchasers of Pennsylvania to help finance his colony. But only in New Jersey did a proprietorship turn into a joint stock holding land company, and it is interesting to see this happening early in the 1680 s when the London proprietors operated as a quasi corporation. ${ }^{28}$

The Barclay papers have most appropriately come to the New Jersey State Archives where they belong because they are 
part of the record of the early history of the state. Some of these materials will help us correct the records that we already have, others are new and will help future historians with a better understanding of its origins. These records, along with the East and West Jersey proprietary records already in the Archives, open new opportunities for research in early New Jersey history. 


\section{Notes}

1. I will always fondly remember Richard P. McCormick's continued support and friendship, as well as appreciate his suggestion shortly before his death that I be asked to write about the Barclay documents. Joseph Klett shared his excitement over the collection with me, as we together tried to unravel the complex puzzle of just what they contained. The staff of the State Archives was, as always, most helpful, as was that of Rutgers University Special Collections and University Archives.

2. The Restoration proprietary colonies included New York, New Jersey, the Carolinas, and Pennsylvania.

3. The East Jersey Fundamental Constitutions were rejected by the colonists and never put into effect.

4. For more than three centuries the proprietors of New Jersey held title to all lands not yet purchased; in other states, at least since the Revolution, these belonged to the state.

5. D. Elton Trueblood, Robert Barclay (New York: Harper \& Row, 1968). Trueblood discusses the Barclay family's Bury Hill manuscripts kept at Ury, but makes no mention of the Record Book or East Jersey Proprietors Minutes; Trueblood, 258-266.

6. Richard S. Dunn et al., eds., The Papers of William Penn vol. 2 (Philadelphia: University of Pennsylvania Press, 1982): 117, 132-134.

7. There are actually more than fifty-six documents as some of the "folios" listed in the index of the book contain several items.

8. I am grateful to J. William Frost, a Quaker historian recently retired from Swarthmore, for information on the provenance of the records.

9. This was published shortly after the collection was purchased by the state. See: Joseph R. Klett, "An Account of East Jersey's Seven Settled Towns, circa 1684," in The Genealogical Magazine of New Jersey 80 (2005), 106-114. 
10. Again the Barclay materials are copies of documents in London made for the governor; these are not "originals." The originals of some documents, such as the deeds, have survived. The fate of others, for example the London Minutes, is unknown but they probably no longer exist.

11. Aaron Leaming and Jacob Spicer, The Grants, Concessions and Original Constitution of the Province of New Jersey (Philadelphia, 1758).

12. Julian Boyd, Fundamental Laws \& Constitutions of New Jersey, 1664-1964 (Princeton: D. Van Nostrand, 1964).

13. Dunn, Papers of Penn vol. 2; and also Jean R. Soderlund et al., eds., William Penn and the Founding of Pennsylvania 1680-1684: A Documentary History (Philadelphia: University of Pennsylvania Press, 1983). The Papers of Penn printed Penn's 1683 Letter to the Proprietors found in the Barclay manuscript, 412-413.

14. Leaming and Spicer, 166. Joseph Klett found this reference.

15. Boyd, in the modern edition of the Fundamental Constitutions used Leaming and Spicer as his source, and then quoted their reservations about the text. He added "No such original is known to be extant." 109. The Barclay Record Book does provide a 1680s copy of the document not previously available to scholars that can be used for comparison.

16. Leaming and Spicer, 166.

17. George J. Miller, ed., vol. 1 The Minutes of the Board of Proprietors of the Eastern Division of New Jersey from 16851705 (Perth Amboy: Board of Proprietors, 1949); Miller ed., vol. 2 Minutes 1725-1744 (Board, 1960); Miller ed., vol. 3 Minutes 1745-1764 (Board, 1960); Maxine N. Lurie \& Joanne R. Walroth eds., Minutes 1764-1794 (Newark: New Jersey Historical Society, 1985).

18. Miller, vol. 2, vii-viii.

19. Dunn, Papers of Penn, vol. 2, 413; Ned C. Landsman, Scotland and Its First American Colony, 1683-1765 (Princeton: Princeton University Press, 1985): 301-302. They are referred to as the Barclay-Bury Hill Papers. 
20. John E. Pomfret, "The Proprietors of the Province of East New Jersey, 1682-1702," Pennsylvania Magazine History \& Biography 77 (1953): 251-293; Pomfret, "The Proprietors of the Province of West New Jersey, 1674-1703," Pennsylvania Magazine History \& Biography 75 (1951): 117-146; Pomfret, The Province of East New Jersey, 1609-1702: The Rebellious Proprietary (Princeton: Princeton University Press, 1962); Pomfret, The Province of West New Jersey, 1609-1702: A History of the Origins of an American Colony (Princeton: Princeton University Press, 1956); Pomfret, The New Jersey Proprietors and their Lands (Princeton: D. Van Nostrand, 1964); and also Pomfret, Colonial New Jersey: A History (New York: Charles Scribner's Sons, 1973).

21. Cunningham, The East of Jersey: A History of the General Board of Proprietors of the Eastern Division of New Jersey (Newark: New Jersey Historical Society, 1992).

22. See especially Landsman, 108-113.

23. John W. Reps, The Making of Urban America: A History of City Planning in the United States (Princeton: Princeton University Press, 1965), especially 89, 151. Reps, and other historians who have discussed the plans for Perth Amboy, never saw this particular map. See Reps, 158.

24. The Minutes include orders and agreements, but are not a complete record of the discussions.

25. Proprietors continued to reside in Scotland and England after 1684 , but there are no known records of their meetings.

26. Pomfret, New Jersey Proprietors \& Lands, 229, 252; Landsman traces the Scots in New Jersey after 1680.

27. For a comparison of proprietary colonies see: Maxine Neustadt Lurie, "Proprietary Purposes in the Anglo-American Colonies: Problems in the Transplantation of English Patterns of Social Organization" (Ph.D. dissertation, University of Wisconsin, 1968).

28. Maxine N. Lurie, "New Jersey: The Unique Proprietary," Pennsylvania Magazine of History \& Biography 111 (1987): 7797. 